\section{Practical pharmacoki- netics as applied to our daily anesthesia practice}

Pierre Fiset MD
A LTHOUGH articles on pharmacokinetics of various intravenous drugs are a familiar part of any anesthesiology journal, the usefulness of the information they convey is not always obvious to the clinician. Most of us still rely on inhalation drugs for maintenance of anesthesia because of ease of administration and decades of accumulated knowledge on the pharmacology of these agents. Nevertheless, recent advances in research on intravenous agents have resulted in new tools and concepts directly applicable to everyday practice and susceptible to greatly improve our ability to administer total intravenous anesthesia. The present review will focus on two aspects of pharmacology that have, or will soon have, an impact on our everyday practice: the advent of commercially available target controlled infusion devices and the recent advances in our understanding of propofol/opioid interactions.

\section{Target Controlled Infusion (TCI) devices}

The use of target controlled infusions allows the titration of the concentration of a drug against clinical effect in individual patients. While the hardware needed for TCIs has been commercially available for some time, these are still used only by a handful of dedicated individuals.

The heart of a TCI device is the infusion program. It contains an algorithm that allows for the calculation of a bolus followed by an infusion to achieve and maintain a target concentration. The infusion rate is usually readjusted every few seconds. Well known versions of those programs are STANPUMP, STELPUMP, RUGLOOP, STANGRAF. ${ }^{2}$ The infusion program contains a library of predetermined pharmacokinetic (PK) parameter sets

a STANPUMP: Steven L, Shafer, Stanford University, Palo Alto. CA, USA. STELPUMP: Johan F. Coetzee, University of Stellenbosch, South Africa. RUGLOOP: Tom de Smet and Michael Struys, University Hospital, Ghent, Belgium. STANGRAF: Phil Scuderi, Bowman Gray University. All these programs are available for download from: pkpd.icon.palo-alto.med.va.gov. for the different drugs used in anesthesia. The anesthesiologist has to choose the set he/she wants to use, but has to understand that the error on the prediction is very dependent on the choice of parameters.

Once the PK set is chosen, the user has a choice to target the plasma or the effect site. Targeting the effect site should, theoretically, result in a quasi-immediate obtaining of the effect, with an overshoot in the plasma. Targeting the plasma will, theoretically, result in immediately obtaining the target plasma concentration ( \pm an error), with a delay in the corresponding effect concentration which will be dependant on the blood-effect site equilibration constant (so called $\mathrm{K}_{\mathrm{eo}}$ ). The program, depending on the PK set chosen, may take into account or ignore the individual characteristics of the patient for the calculation of the infusion.

The uncertainty surrounding the use of TCI comes from the existence of many different PK sets for the same drug. Which one will provide the clinician with the best accuracy and the smallest error? This question can only be answered with the help of controlled studies evaluating the prospective performance of TCIs. Propofol pharmacokinetics have recently undergone a rigorous validation process. The results of Coetzee et al. and Vuyk et al. are reported in Table I. The performance error is calculated as:

$$
P E=\frac{\mathrm{C} m-\mathrm{C} p}{\mathrm{C} m} \star 100
$$

Where $\mathrm{PE}$ is the prediction error expressed in percentage, $\mathrm{C}_{m}$ is the concentration measured in the blood and $\mathrm{C}_{\mathrm{p}}$ is the target concentration.

It is obvious from Table I that some data sets perform better than others. The reasons for this are still a matter of speculation but are probably related to factors like the site of blood sampling (venous $p s$ arterial), the similarity between the population of origin of the PK set and the one for which the TCI is used and the levels of propofol targeted $v s$ their effect on hemodynamics. 


\begin{tabular}{|c|c|c|c|c|c|}
\hline Study & $\begin{array}{l}\text { Pharmacokinetic } \\
\text { Parameters }\end{array}$ & $\begin{array}{l}\text { MDPE } \\
(\%) \\
\text { Bias }\end{array}$ & $\begin{array}{l}\text { MDAPE } \\
\text { (\%) } \\
\text { Inaccuracy }\end{array}$ & $\begin{array}{l}\text { Divergence } \\
(\% / 60 \mathrm{~min})\end{array}$ & $\begin{array}{l}\text { MDADPE } \\
\text { (\%) Wobble }\end{array}$ \\
\hline Vuyk $^{3}$ & Gepts ${ }^{8}$ & 26 & 27 & 42 & 17 \\
\hline \multirow[t]{4}{*}{ Group A } & Shafer ${ }^{9}$ & 21 & 22 & 49 & 17 \\
\hline & Kirkpatrick $^{10}$ & 112 & 112 & 53 & 24 \\
\hline & Cockshott ${ }^{11}$ & 22 & 23 & 31 & 15 \\
\hline & Tackley ${ }^{12}$ & 27 & 29 & 31 & 14 \\
\hline Vuyk $^{3}$ & Gepts & 25 & 28 & 2 & 24 \\
\hline \multirow[t]{4}{*}{ Group B } & Shafer & 26 & 30 & 4 & 26 \\
\hline & Kirkpatrick & 94 & 94 & -18 & 36 \\
\hline & Cockshott & 19 & 23 & 1 & 22 \\
\hline & Tackley & 22 & 25 & 1 & 23 \\
\hline \multirow[t]{3}{*}{ Coetzee $^{2}$} & Marsh $^{6}$ & -7 & 18.2 & 6.5 & 10 \\
\hline & Dyck \& Shafer ${ }^{13}$ & 36.4 & 39.3 & 14.6 & 12 \\
\hline & Tackley & -4.6 & 20.6 & 6.9 & 14 \\
\hline \multirow[t]{3}{*}{ Glen ${ }^{4}$} & Tackley & 9 & 25 & & \\
\hline & Marsh & 5.7 & 25.5 & & \\
\hline & Dyck \& Shafer & 21 & 26 & & \\
\hline Swinhoe 6 & Marsh & & & & \\
\hline \multirow[t]{3}{*}{ "Diprifusor" } & $18-40$ years old & 13.8 & 22.6 & & \\
\hline & $41-55$ years old & 17.7 & 25 & & \\
\hline & $56-80$ years old & 16.2 & 24.2 & & \\
\hline
\end{tabular}

MDPE (bias) = percentage median prediction error

MDAPE (inaccuracy) $=$ percentage median absolute prediction error Divergence $=\mathrm{A}$ measure in percentage of the effect of time on the prediction error MDADPE (wobble) = Intrasubject variability of prediction error

Prospective validation studies have led to the introduction, in Europe, of the first commercially available TCI device: the "Diprifusor"b system, designed specifically for the infusion of propofol. Table I also shows the prospective validation data from Glen et al. that led to the choice of the Marsh et al. pharmacokinetic set for Diprifusor. The data from Swinhoe et al. show the performance of Diprifusor in a heterogenous population ranging from 18 to $80 \mathrm{yr}$ of age during various surgical procedures. These results confirm that a rigorous validation process allows for the precise administration of propofol using a TCI device in the clinical setting. It is predictable that TCIs will gain more acceptance among clinicians and that validation for the administration of other drugs will still improve the accuracy and the ease of use of TIVA.

\section{Propofol/opioid interactions}

Using TCI devices presupposes that the concentrations targeted correspond to precise and reliable clini-

\footnotetext{
b Diprifusor is a trademark of Zeneca Pharma.
}

cal endpoints. In anesthesia, a solid scientific process for the determination of concentration-effect relationships has been established after decades of research with inhalation drugs due to the early, non-invasive and reliable availability of their concentration measurement. This has led to the concept of minimum alveolar concentration (MAC) which is used as a unit of potency by clinicians in everyday practice as well as by researchers for sophisticated conceptual work. For intravenous drugs, concentration measurements must be done using blood sampling, a much more complex process. Nevertheless, the determination of concentration-effect relationships for intravenous anesthetics has recently been evolving considerably.

For a drug like propofol, which is used for maintenance as an hypnotic agent during TIVA, it is important to know the concentration at which consciousness will be lost. The plasma concentration needed to prevent a response (verbal command, light touch) in $50 \%$ of people, the Cp50-awake, is the conceptual equivalent of the MAC-awake. Table II shows the results from four different studies aimed at the determination of propofol Cp50-awake. Looking at the Cp95 column, it is fair to 
conclude that about $5.0 \mu \mathrm{g} \cdot \mathrm{ml}^{-1}$ is the minimum plasma concentration to be maintained in order to avoid awareness if propofol is used as a sole agent.

Anesthesiologists almost never give a single agent for general anesthesia, hence the need for studies that will determine the response to noxious stimulation after the administration of a combination of drugs. Vuyk et al. have determined the interaction profile of propofol and alfentanil for a series of stimuli as well as for return of consciousness and derived interaction curves allowing the determination of concentration combinations (respective Cp50) of the two agents corresponding to a $50 \%$ chance of responding to intra-abdominal surgical stimuli. A response was defined as:

1. An increase in systolic blood pressure by $>15$ mmHg above normal.

2. A heart rate $>90$ beats $\cdot \mathrm{min}^{-1}$ in the absence of hypovolemia.

3. Other autonomic signs such as sweating of flushing.

4. Somatic responses such as movement or swallowing.

In a later publication, Vuyk et al. extrapolated their model to other propofol/opioid combinations. First, they determined the $\mathrm{C}_{\mathrm{P}} 95$ combinations from their original propofol/alfentanil data to obtain a target

TABLE II Propofol $\mathrm{EC}_{50}$ and $\mathrm{EC}_{95}$ for loss of consciousness.

\begin{tabular}{|c|c|c|c|}
\hline Study & $\begin{array}{l}\text { Stimulus for testing } \\
\text { loss of consciousness }\end{array}$ & $\begin{array}{l}C p 50 \\
\left(\mu g \cdot k g^{-1}\right)\end{array}$ & $\begin{array}{l}C p 95 \\
\left(\mu g \cdot g^{-1}\right)\end{array}$ \\
\hline Vuyk et al. $1992^{13}$ & Tactile stimulus & 3.4 & 4.34 \\
\hline Forrest et al. 1994.14 & $\begin{array}{l}\text { Open eyes on } \\
\text { command }\end{array}$ & 2.3 & \\
\hline Smith et al. $1994^{15}$ & $\begin{array}{l}\text { Open eyes on } \\
\text { command }\end{array}$ & 3.3 & 5.4 \\
\hline Chortkoff et al. $1995^{16}$ & "Squeeze my hand" & 2.69 & \\
\hline
\end{tabular}

that would be more clinically relevant (we want all of our patients to be unresponsive, not only $50 \%$ of them). From their interaction model they simulated infusions of various durations and, using previously derived pharmacokinetic data, determined the recovery profile of the various combination to determine which was the most advantageous from the aspect of return of consciousness. Finally, using published potency ratios for alfentanil, fentanyl, sufentanil and remifentanil, they produced an elaborate series of dosing guidelines for propofol/opioid combinations that would produce the fastest emergence.

Table III has been adapted and simplified from Vuyk et al., and represents the combination of target concentrations ( $\mathrm{Cp} 50)$ and corresponding infusions needed to abolish the response to surgical stimuli in $50 \%$ of patients, so that either a TCI device or a manual infusion can be used. These combinations will result in the fastest emergence. It is worth noting that the propofol infusion scheme is the same for alfentanil, fentanyl and sufentanil. According to the model, increasing the effect site concentrations from $\mathrm{Cp} 50$ to Cp95 is done by increasing the propofol concentration by $30 \%$ and the fentanyl, sufentanil and remifentanil concentrations by $25 \%$. Practically, this implies that changes in depth of anesthesia are made by changing both infusions proportionally. Hence, to deepen anesthesia, each infusion (or each target if a TCI is used) is increased by the same percentage. The model also tells us that, if remifentanil is used, the ideal way to change levels of anesthesia is to change the remifentanil infusion rate and keep the propofol rate constant.

The Cp50 has been chosen for Table III because it probably represents good starting guidelines in reallife situations. The initial bolus corresponds to reasonable induction doses and the depth of anesthesia

TABLE III Suggested effect-site $\mathrm{EC}_{50}$ and infusion rates of propofol/opiod combinations associated with a 50\% chance of no response to intra-abdominal surgical stimulus that will result in the fastest awakening. Adapted from Vuyk et al., Anesthesiology 1997; 87: 1549-62.

\begin{tabular}{|c|c|c|c|c|}
\hline & Propofol/Alfentanil & Propofol/Fentanyl & Propofol/Sufentanil & Propofol/Remifentanil \\
\hline $\mathrm{EC}_{50}\left(\mu \mathrm{g} \cdot \mathrm{ml}^{-1} / \mathrm{ng} \cdot \mathrm{ml}^{-1}\right)$ & $3.38 / 89.7$ & $3.42 / 1.26$ & $3.34 / 0.14$ & $2.51 / 4.78$ \\
\hline Awake (min) & 12.2 & 2.4 & 11.9 & 6.1 \\
\hline \multicolumn{5}{|c|}{ Propofol administration } \\
\hline $\begin{array}{l}\text { Bolus } \\
\text { Infusion } 1 \\
\text { Infusion } 2 \\
\text { Infusion } 3\end{array}$ & $\begin{array}{l}2 \mathrm{mg} \cdot \mathrm{kg}^{-1} \text { in } 30 \mathrm{sec} \\
9 \mathrm{mg} \cdot \mathrm{kg}^{-1} \cdot \mathrm{hr}^{-1} \text { for } 40 \mathrm{~min} \\
7 \mathrm{mg} \cdot \mathrm{kg}^{-1} \cdot \mathrm{h}^{-1} \text { for } 150 \mathrm{~min} \\
6.5 \mathrm{mg} \cdot \mathrm{kg}^{-1} \cdot \mathrm{hr}^{-1} \text { thereafter }\end{array}$ & $\begin{array}{l}2 \mathrm{mg} \cdot \mathrm{kg}^{-1} \text { in } 30 \mathrm{sec} \\
9 \mathrm{mg} \cdot \mathrm{kg}^{-1} \cdot \mathrm{hr}^{-1} \text { for } 40 \mathrm{~min} \\
7 \mathrm{mg} \cdot \mathrm{kg}^{-1} \cdot \mathrm{h}^{-1} \text { for } 150 \mathrm{~min} \\
6.5 \mathrm{mg} \cdot \mathrm{kg}^{-1} \cdot \mathrm{hr}^{-1} \text { thereafter }\end{array}$ & $\begin{array}{l}2 \mathrm{mg} \cdot \mathrm{kg}^{-1} \text { in } 30 \mathrm{sec} \\
9 \mathrm{mg} \cdot \mathrm{kg}^{-1} \cdot \mathrm{hr}^{-1} \text { for } 40 \mathrm{~min} \\
7 \mathrm{mg} \cdot \mathrm{kg}^{-1} \cdot \mathrm{h}^{-1} \text { for } 150 \mathrm{~min} \\
6.5 \mathrm{mg} \cdot \mathrm{kg}^{-1} \cdot \mathrm{hr}^{-1} \text { thereafter }\end{array}$ & $\begin{array}{l}1.5 \mathrm{mg} \cdot \mathrm{kg}^{-1} \text { in } 30 \mathrm{sec} \\
7 \mathrm{mg} \cdot \mathrm{kg}^{-1} \cdot \mathrm{hr}^{-1} \text { for } 40 \mathrm{~min} \\
6 \mathrm{mg} \cdot \mathrm{kg}^{-1} \cdot \mathrm{h}^{-1} \text { for } 150 \mathrm{~min} \\
5 \mathrm{mg} \cdot \mathrm{kg}^{-1} \cdot \mathrm{hr}^{-1} \text { thereafter }\end{array}$ \\
\hline \multicolumn{5}{|l|}{ Opioid administration } \\
\hline $\begin{array}{l}\text { Bolus } \\
\text { Infusion } 1 \\
\text { Infusion } 2 \\
\text { Infusion } 3\end{array}$ & $\begin{array}{l}25 \mu \mathrm{g} \cdot \mathrm{kg}^{-1} \text { in } 30 \mathrm{sec} \\
50 \mu \mathrm{gg} \cdot \mathrm{kg}^{-1} \cdot \mathrm{hr}^{-1} \text { for } 30 \mathrm{~min} \\
30 \mu \mathrm{g} \cdot \mathrm{kg}^{-1} \cdot \mathrm{hr}^{-1} \text { thereafter }\end{array}$ & $\begin{array}{l}3 \mu \mathrm{g} \cdot \mathrm{kg}^{-1} \text { in } 30 \mathrm{sec} \\
1.5 \mu \mathrm{g} \cdot \mathrm{kg}^{-1} \cdot \mathrm{h}^{-1} \text { for } 30 \mathrm{~min} \\
1.3 \mu \mathrm{g} \cdot \mathrm{kg}^{-1} \cdot \mathrm{hr}^{-1} \text { for } 120 \mathrm{~min} \\
0.7 \mu \mathrm{g} \cdot \mathrm{kg}^{-1} \cdot \mathrm{hr}^{-1} \text { thereafter }\end{array}$ & $\begin{array}{l}0.15 \mu \mathrm{g} \cdot \mathrm{kg}^{-1} \text { in } 30 \mathrm{sec} \\
0.15 \mu \mathrm{g} \cdot \mathrm{kg}^{-1} \cdot \mathrm{hr}^{-1} \text { thereafter } \\
11.5 \mu \mathrm{kg} \cdot \mathrm{kg}^{-1} \cdot \mathrm{hr}^{-1} \text { thereafter }\end{array}$ & $\begin{array}{l}1.5 \mu \mathrm{g} \cdot \mathrm{kg}^{-1} \text { in } 30 \mathrm{sec} \\
13 \mu \mathrm{g} \cdot \mathrm{kg}^{-1} \cdot \mathrm{hr}^{-1} \text { for } 20 \mathrm{~min}\end{array}$ \\
\hline
\end{tabular}


needed for skin preparation is certainly no more than the Cp50 obtained with the infusion rates recommended. Adequate planning will allow the clinician to deepen the level of anesthesia in anticipation of skin incision by applying the proportional changes principle described above.

A few points need to be made concerning the clinical application of this model. Ideally, a TCI device should be used. When changes in effect site concentrations are made, they happen almost immediately as a consequence of the administration of a bolus followed by an infusion. As most clinicians will use manual infusions, they must realize that changes in depth of anesthesia will occur more slowly. It is also worth noting that the respective combination of propofol/opioid (target concentrations) remains the same independent of the length of infusion, but recovery times are longer with longer infusions.

The use of the propofol/remifentanil combination needs to be put in perspective. Table III shows that the propofol Cp50 obtained with the infusion rate proposed is $2.5 \mu \mathrm{g} \cdot \mathrm{ml}^{-1}$. As shown in Table II, this concentration will result in response to verbal commands in $\mathbf{5 0 \%}$ of subjects. If the dosing guidelines are followed and the remifentanil infusion is inadvertently interrupted, the opioid levels will decrease very rapidly and a significant proportion of patients might experience awareness. In view of this problem, it is probably safer to run a slightly higher infusion rate of propofol and a lower infusion of remifentanil. According to Vuyk's simulations, recovery would still happen rapidly.

Finally, consideration should still be given to individual factors such as age, physiological status, weight and disease processes, which can all influence pharmacokinetic and pharmacodynamic behaviour. Again, better modeling techniques and sophisticated studies will improve our understanding and result in better dosing recommendations. This is nicely exemplified in a recent study by Egan et al. where the authors showed that remifentanil administration should be based on lean rather than total body mass. In the accompanying editorial, Bouillon and Shafer suggest a nomogram for determination of the weight that should be used for scaling. These recommendations should probably applied to the infusion rates suggested in Table III.

Better understanding of pharmacology results in better care for the patient. Empirical knowledge, common sense and astute clinical observation certainly help in establishing sensible dosing guidelines, but scientific evidence is needed to fully understand the complexity of pharmacology and drug interaction.

\section{References}

1 Gepts E. Pharmacokinetic concepts for TCI anaesthesia. Anaesthesia 1998; 53: 4-12.

2 Varvel JR, Donobo DL, Shafer $S L$. Measuring the predictive performance of computer controlled infusions. J Pharmacokinet Biopharm 1992; 20: 63-94.

3 Coetzee JF, Glen JB, Wium CA, Boshoff $L$. Pharmacokinetic model selection for target controlled infusions of propofol. Anesthesiology 1995; 82: $1328-45$.

4 Vuyk J, Engbers FHM, Burm AGL, Vletter AA, Bovill $J G$. Performance of computer-controlled infusion of propofol: an evaluation of five pharmacokinetic parameter sets. Anesth Analg 1995; 81: 1275-82.

5 Glen JB. The development of "Diprifusor": a TCI system for propofol. Anaesthesia 1998; 53: 13-21.

6 Marsh B, White M, Morton N, Kenny NC. Pharmacokinetic model driven infusion of propofol in children. Br J Anaesth 1991; 67: 41-8.

7 Swinhoe CF, Peacock JE, Glen.JB, Reilly CS. Evaluation of the predictive performance of a "Diprifusor" TCI system. Anaesthesia 1998; 53: 61-7.

8 Gepts E, Camu F, Cockshott ID, Douglas J. Disposition of propofol administered as constant rate intravenous infusions in humans. Anesth Analg 1987; 66: 1256-63.

9 Shafer A, Doze VA, Shafer SL, White PF. Pharmacokinetics and pharmacodynamics of propofol infusions during general anesthesia. Anesthesiology 1988; 69: 348-56.

10 Kirkpatrick T, Cockshott ID, Douglas EJ, Nimmo WS. Pharmacokinetics of propofol (diprivan) in elderly patients. Br J Anaesth 1988; 60: 146-50.

11 Cockshott ID, Briggs LP, Douglas EJ, White $M$. Pharmacokinetics of propofol in female patients. $\mathrm{Br} \mathrm{J}$ Anaesth 1987; 59: 1103-10.

12 Tackley RM, Lewis GTR, Prys-Roberts C, Boaden RW, Dixon J, Harvey JT. Computer controlled infusion of propofol. Br J Anaesth 1989; 62: 46-53.

13 Chortkoff BS, Eger EI, Crankshaw DP, Gonsowski CT, Dutton $R C$, Ionescu P. Concentrations of desflurane and propofol that suppress response to command in humans. Anesth Analg 1995; 81: 737-43.

14 Vuyk J, Engbers FHM, Lemmens HJM, et al. Pharmacodynamics of propofol in female patients. Anesthesiology 1992; 77: 3-9.

15 Forrest FC, Tooley MA, Saunders PR, Prys-Roberts $C$. Propofol infusion and the suppression of consciousness: the EEG and dose requirements. $\mathrm{Br} \mathrm{J}$ Anaesth 1994; 72: 35-41.

16 Smith C, McEwan AI, Jhaperi R, et al. The interaction of fentanyl on the $\mathrm{Cp} 50$ of propofol for loss of consciousness and skin incision. Anesthesiology 1994; 81: 820-8. 
17 Vuyk J, Lim T, Engbers FHM, Burm AGL, Vletter AA, Bovill $J G$. The pharmacodynamic interaction of propofol and alfentanil during lower abdominal surgery in women. Anesthesiology 1995; 83: 8-22.

18 Vuyk J, Mertens MJ, Olofsen E, Burm AGL, Bovill JG. Propofol anesthesia and rational opioid selection. Anesthesiology 1997; 87; 1549-62.

19 Shafer SL, Varvel JR. Pharmacokinetics, pharmacodynamics, and rational opioid selection. Anesthesiology 1991; 74: 53-63.

20 Egan TD, Minto CF, Hermann DJ, Barr JB, Muir KT, Shafer SL. Remifentanil versus alfentanil. Anesthesiology 1996; 84: 821-33.

21 Egan TD, Huizinga B, Gupta $S$, et al. Remifentanil pharmacokinetics in obese versus lean patients. Anesthesiology 1998; 89: 562-73.

22 Bouillon T, Shafer SL. Does size matter? Anesthesiology 1998; 89: 557-60. 


\section{La pharmacocinétique appliquée à la pratique courante de l'anesthésie}

B IEN que la pharmacocinétique de divers médicaments intraveineux fasse habituellement partie des articles de tout journal d'anesthésiologie, l'utilité des renseignements dont elle fait l'objet n'est pas toujours évidente au clinicien. La majorité d'entre nous compte sur les médicaments volatils pour maintenir l'anesthésie, puisque l'administration par inhalation en est plus facile et qu'il existe une foule de connaissances pharmacologiques accumulées depuis des décennies à leur sujet. Néanmoins, les récentes découvertes sur les agents intraveineux ont fourni des outils et des concepts nouveaux directement applicables dans la pratique courante et susceptibles d'améliorer grandement notre habileté à administrer l'anesthésie exclusivement intraveineuse (AEI). Notre mise à jour met l'accent sur deux aspects de la pharmacologie qui ont, ou auront bientôt, un impact sur notre pratique quotidienne : l'arrivée de dispositifs commercialement offerts pour la perfusion cible contrôlée et les connaissances nouvelles des interactions entre propofol et opioïde.

Dispositifs de perfusion cible contrôlee (PCC) L'emploi de perfusions cibles contrôlées permet le titrage de la concentration d'un médicament en vue d'un effet clinique individuel chez les patients. Commercialement offert depuis peu, le matériel nécessaire à la PCC n'est encore utilisé que par une poignée d'individus convaincus.

Le programme de perfusion est au cour d'un dispositif de PCC. Il contient un algorithme qui tient compte du calcul d'un bolus suivi d'une perfusion pour établir une concentration cible et la maintenir. En général, la vitesse de perfusion est réajustée à intervalles réguliers de quelques secondes. Les versions connues des programmes sont STANPUMP, STELPUMP, RUGLOOP, STANGRAF. ${ }^{a}$ Le programme contient

a STANPUMP: Steven L. Shafer, Stanford University, Palo Aito. CA, USA. STELPUMP: Johan F. Coetzee, University of Stellenbosch, South Africa. RUGLOOP: Tom de Smet and Michael Struys, University Hospital, Ghent, Belgium. STANGRAF: Phil Scuderi, Bowman Gray University. Tous ces programmes sont disponibles pour téléchargement: pkpd.icon.palo-alto.med.va.gov. une bibliothèque de paramètres pharmacocinétiques (PC) prédéterminés, réglés pour différents anesthésiques. L'anesthésiologiste doit choisir l'ensemble désiré, mais doit savoir que l'erreur de prédiction dépend beaucoup du choix des paramètres.

Une fois les PC choisis, on peut décider de la cible : plasma ou site effecteur. Cibler le site effecteur devrait, en théorie, produire l'effet quasi immédiat et entrầner une concentration plasmatique maximale. Cibler le plasma devrait, en théorie, fournir la concentration plasmatique cible immédiate (une erreur), avec un délai d'obtention de la concentration correspondante au site effecteur, laquelle dépendra de la constante d'équilibre (appelée $\mathrm{K}_{\mathrm{eo}}$ ) entre les concentrations plasma-site effecteur. Le programme de l'ensemble PC choisi, peut tenir compte ou non des caractéristiques individuelles du patient dans le calcul de la perfusion.

L'incertitude entourant l'utilisation de PCC vient de l'existence de nombreux ensembles PC différents pour un même médicament. Lequel fournira au clinicien le rendement le plus précis, mais la moindre erreur ? On ne peut répondre à cette question qu'avec l'aide d'études contrôlées qui évaluent la performance prédite des PCC. La pharmacocinétique du propofol a subi récemment un exercice de validation rigoureux. Les résultats de Coetzee et coll. et Vuyk et coll. apparaissent à la Table I. L'erreur de performance est calculée de la manière suivante :

$$
P E=\frac{\mathrm{C} m-\mathrm{C} p}{\mathrm{C} m} * 100
$$

PE représente l'erreur de prédiction exprimée en pourcentage, $\mathrm{C}_{\mathrm{m}}$ est la concentration mesurée dans le sang et $\mathrm{C}_{\mathrm{p}}$ est la concentration plasmatique cible.

C'est évident, selon la Table I, que certains ensembles de données produisent de meilleurs résultats que d'autres. Rien ne permet encore d'expliquer ce fait qui est sans doute lié à des facteurs comme le site de l'échantillon sanguin (veine vs artère), la similarité entre les populations choisies pour l'utilisation de l'ensemble PC et pour celle de la PCC et les niveaux 
TABLE I

\begin{tabular}{|c|c|c|c|c|c|}
\hline \multirow[t]{2}{*}{ Étude } & $\begin{array}{l}\text { Pharmacocinétique } \\
\text { Paramètres }\end{array}$ & $\begin{array}{l}\text { MDPE } \\
(\%)\end{array}$ & $\begin{array}{l}\text { MDAPE } \\
(\%)\end{array}$ & $\begin{array}{l}\text { Divergence } \\
(\% / 60 \mathrm{~min})\end{array}$ & $\begin{array}{l}\text { MDADPE } \\
\text { Fluctuations } \\
\text { (\%) }\end{array}$ \\
\hline & & Biais & Inexactitude & & \\
\hline Vuyk $^{3}$ & Gepts ${ }^{8}$ & 26 & 27 & 42 & 17 \\
\hline \multirow[t]{4}{*}{ Groupe A } & Shafer ${ }^{9}$ & 21 & 22 & 49 & 17 \\
\hline & Kirkpatrick $^{10}$ & 112 & 112 & 53 & 24 \\
\hline & Cockshott $^{11}$ & 22 & 23 & 31 & 15 \\
\hline & Tackley ${ }^{12}$ & 27 & 29 & 31 & 14 \\
\hline Vuyk ${ }^{3}$ & Gepts & 25 & 28 & 2 & 24 \\
\hline \multirow[t]{4}{*}{ Groupe B } & Shafer & 26 & 30 & 4 & 26 \\
\hline & Kirkpatrick & 94 & 94 & -18 & 36 \\
\hline & Cockshott & 19 & 23 & 1 & 22 \\
\hline & Tackley & 22 & 25 & 1 & 23 \\
\hline \multirow[t]{3}{*}{ Coetzee $^{2}$} & Marsh $^{6}$ & -7 & 18,2 & 6,5 & 10 \\
\hline & Dyck \& Shafer ${ }^{13}$ & 36,4 & 39,3 & 14,6 & 12 \\
\hline & Tackley & $-4,6$ & 20,6 & 6,9 & 14 \\
\hline \multirow[t]{3}{*}{ Glen ${ }^{4}$} & Tacklcy & 9 & 25 & & \\
\hline & Marsh & 5,7 & 25,5 & & \\
\hline & Dyck \& Shafer & 21 & 26 & & \\
\hline Swinhoe 6 & Marsh & & & & \\
\hline \multirow[t]{3}{*}{ «Diprifusor» } & $18-40$ ans & 13,8 & 22,6 & & \\
\hline & $41-55$ ans & 17,7 & 25 & & \\
\hline & $56-80$ ans & 16,2 & 24,2 & & \\
\hline
\end{tabular}

MDPE (biais) - médiane de l'erreur de prédiction (exprimée en \%)

MDAPE (inexactitude) = médiane de l'erreur absolue de prédiction (exprimée en \%)

Divergence = Une mesure en pourcentage de l'effet du temps sur l'erreur de prédiction

MDADPE (fluctuations) = Variabilité intra-individuelle de l'erreur de prédiction

de propofol ciblés vs leurs effets hémodynamiques. Grâce à des études prospectives de validation, on a pu commercialiser, en Europe, le premier dispositif de PCC : le système «Diprifusor» ${ }^{\mathrm{b}}$, conçu spécialement pour le propofol. La Table I présente aussi les données de la validation prospective de Glen et coll. qui ont guidé Marsh et coll. dans leur choix de paramètres pharmacocinétiques pour le Diprifusor. Les données de Swinhoe et coll. montrent la performance du Diprifusor chez une population hétérogène de 18 à 80 ans pendant différentes interventions chirurgicales. Les résultats confirment qu'une validation rigoureuse tient compte de l'administration précise de propofol à l'aide d'appareil de PCC en clinique. On peut prévoir que la PCC sera davantage acceptée par les cliniciens et que la validation qui vise à administrer d'autres médicaments améliorera encore la précision et la facilité d'emploi de l'AEI (anesthésie exclusivement intraveineuse).

\footnotetext{
${ }^{b}$ Diprifusor est une marque de commerce de Zeneca Pharma.
}

\section{Interactions propofol/opioïde}

L'utilisation des dispositifs de PCC présuppose que la concentration ciblée correspond à des besoins cli-s niques réels et précis. Après des décennies de recherches avec des médicaments volatils, on a établi en anesthésie un procédé scientifique pratique pour déterminer les relations concentration-effet grâce à la possibilité d'une mesure précoce non effractive et fiable de leur concentration. C'est ce qui a mené au concept de concentration alvéolaire minimale (CAM) qui est utilisé quotidiennement comme unité de puissance par les cliniciens autant que par les chercheurs pour des travaux théoriques sophistiqués. Par contre, pour mesurer les concentrations des médicaments intraveineux, il faut prélever des échantillons sanguins, ce qui est beaucoup plus complexe. Néanmoins, la façon de déterminer les relations concentration-effet pour les anesthésiques intraveineux a connu récemment une considérable évolution.

Quand on utilise un médicament comme le propofol en qualité d'agent hypnotique pour le maintien de I'AEI, il faut savoir avec quelle concentration se produira la perte de conscience. La concentration plasma- 
tique nécessaire pour empêcher une réaction (à une commande verbale, au toucher léger) chez $50 \%$ des gens, la $\mathrm{Cp}_{50}$ d'éveil, est le concept équivalent de la CAM d'éveil. La Table II montre les résultats de quatre études différentes qui avaient pour but de déterminer la $\mathrm{Cp}_{50}$ d'éveil du propofol. En regard de la colonne $\mathrm{Cp}_{95}$, il est logique de conclure qu'il faut maintenir une concentration plasmatique minimale d'environ $5,0 \mu \mathrm{g} \cdot \mathrm{ml}^{-1}$ pour éviter le retour à la conscience, si le propofol est le seul agent utilisé.

Les anesthésiologistes n'administrent rarement qu'un seul agent pour l'anesthésie générale, d'où la nécessité d'études qui pourront déterminer la réponse à une stimulation désagréable après l'administration d'une combinaison de médicaments. Vuyk et coll. ont déterminé le profil d'interaction du propofol et de l'afentanil pour une série de stimuli et pour le retour de la conscience et ont dérivé les courbes d'interaction qui déterminent les combinaisons de concentrations (selon la $\mathrm{Cp} 50$ ) des deux agents correspondant à $50 \%$ de réponse à des stimulations chirurgicales intraabdominales. Une réponse était définie comme suit :

TABLE II $\mathrm{CE}_{50}$ er $\mathrm{CE}_{95}$ du propofol pour la perte de conscience

\begin{tabular}{|c|c|c|c|}
\hline Étude & $\begin{array}{l}\text { Stimulus du test } \\
\text { perte de conscience }\end{array}$ & $\begin{array}{l}C p_{50} \\
\left(\mu g \cdot k g^{-1}\right)\end{array}$ & $\begin{array}{l}C p_{95} \\
\left(\mu g \cdot k g^{l}\right)\end{array}$ \\
\hline Vuyk et coll. $1992^{13}$ & Stimulus tactile & 3,4 & 4,34 \\
\hline Forrest et coll. $1994^{14}$ & $\begin{array}{l}\text { Yeux ouverts sur } \\
\text { commande }\end{array}$ & 2,3 & \\
\hline Smith et coll. $1994^{15}$ & $\begin{array}{l}\text { Yeux ouverts sur } \\
\text { commande }\end{array}$ & 3,3 & 5,4 \\
\hline Chortkoff et coll. $1995^{16}$ & «Serrez ma main» & 2,69 & \\
\hline
\end{tabular}

1. Une hausse de tension artérielle systolique de $>15$ $\mathrm{mmHg}$ au-dessus de la normale.

2. Une fréquence cardiaque $>90$ battements $\mathrm{min}^{-1}$ en l'absence d'hypovolémie.

3. D'autres signes autonomes comme la transpiration ou les rougeurs.

4. Des réponses somatiques comme le mouvement ou la déglutition.

Dans un article ultérieur, Vuyk et coll. ont extrapolé leur modèle à d'autres combinaisons propofol/opioïde. D'abord, ils ont déterminé les combinaisons de $\mathrm{Cp}_{95}$, sur la base de leurs données originales obtenues avec le propofol/alfentanil, pour obtenir une cible applicable en clinique. (tous les patients doivent être inconscients, non seulement $50 \%$ d'entre eux). À partir de leur modèle d'interaction, ils ont simulé des perfusions de durée variable et, à l'aide des données pharmacocinétiques dérivées auparavant, ils ont déterminé le profil de récupération avec diverses combinaisons pour en arriver à celle qui favorisera le retour à la conscience. Finalement, en utilisant les ratios de puissance connus pour l'alfentanil, le fentanyl, le sufentanil et le rémifentanil, ils ont produit une série élaborée de schémas de dosage pour des combinaisons de propofol/opioïde qui pourraient produire le réveil le plus rapide.

La Table III, adaptée de Vuyk et coll., a été simplifiée et représente la combinaison de concentrations cibles $\left(\mathrm{CP}_{50}\right)$ et les perfusions correspondantes nécessaires pour abolir la réponse aux stimulations chirurgicales chez $50 \%$ des patients, de façon à permettre l'utilisation d'un dispositif à PCC ou une perfusion manuelle. Ces combinaisons vont produire le réveil le plus rapide. Notons ici les schémas de perfusion iden-

TABLE III $\mathrm{CE}_{50}$ du site effecteur suggérées et vitesses de perfusion de combinaisons de propofol/opioïde associées à $50 \%$ d'absence de réponse à un stimulus chirurgical intra-abdominal, ce qui provoquera le réveil le plus rapide. Adapté de Vuyk et coll., Anesthesiology 1997; 87: $1549-62$.

\begin{tabular}{|c|c|c|c|c|}
\hline & Propofol/Alfentanil & Propofol/Fentanyl & Propofol/Sufentanil & Propofol/Rémifentanil \\
\hline $\begin{array}{l}\mathrm{CE}_{50}\left(\mu \mathrm{g} \cdot \mathrm{ml}^{-1} / \mathrm{ng} \cdot \mathrm{ml}^{-1}\right) \\
\text { Éveil (min) } \\
\text { Administration de } \\
\text { propofol }\end{array}$ & $\begin{array}{l}3,38 / 89,7 \\
12,2\end{array}$ & $\begin{array}{l}3,42 / 1,26 \\
12,4\end{array}$ & $\begin{array}{l}3,34 / 0,14 \\
11,9\end{array}$ & $\begin{array}{l}2,51 / 4,78 \\
6,1\end{array}$ \\
\hline $\begin{array}{l}\text { Bolus } \\
\text { Perfusion 1 } \\
\text { Perfusion 2 } \\
\text { Perfusion 3 } \\
\text { Administration } \\
\text { d'opiöde }\end{array}$ & $\begin{array}{l}2 \mathrm{mg} \cdot \mathrm{kg}^{-1} \text { en } 30 \mathrm{~s} \\
9 \mathrm{mg} \cdot \mathrm{kg}^{-1} \cdot \mathrm{h}^{-1} \times 40 \mathrm{~min} \\
7 \mathrm{mg} \cdot \mathrm{kg}^{-1} \cdot \mathrm{h}^{-1} \times 150 \mathrm{~min} \\
6,5 \mathrm{mg} \cdot \mathrm{kg}^{-1} \cdot \mathrm{h}^{-1} \text { ensuite }\end{array}$ & $\begin{array}{l}2 \mathrm{mg} \cdot \mathrm{kg}^{-1} \text { en } 30 \mathrm{~s} \\
9 \mathrm{mg} \cdot \mathrm{kg}^{-1} \times \mathrm{h}^{-1} \text { x } 40 \mathrm{~min} \\
7 \mathrm{mg} \cdot \mathrm{kg}^{-1} \cdot \mathrm{h}^{-1} \times 150 \mathrm{~min} \\
6,5 \mathrm{mg} \cdot \mathrm{kg}^{-1} \cdot \mathrm{h}^{-1} \text { ensuite }\end{array}$ & $\begin{array}{l}2 \mathrm{mg} \cdot \mathrm{k}^{-1} \text { en } 30 \mathrm{~s} \\
9 \mathrm{mg} \cdot \mathrm{kg}^{-1} \cdot \mathrm{h}^{-1} \times 40 \mathrm{~min} \\
7 \mathrm{mg} \cdot \mathrm{kg}^{-1} \cdot \mathrm{h}^{-1} \times 150 \mathrm{~min} \\
6,5 \mathrm{mg} \cdot \mathrm{kg}^{-1} \cdot \mathrm{h}^{-1} \text { ensuite }\end{array}$ & $\begin{array}{l}1,5 \mathrm{mg} \cdot \mathrm{kg}^{-1} \text { en } 30 \mathrm{~s} \\
7 \mathrm{mg} \cdot \mathrm{kg}^{-1} \cdot \mathrm{h}^{-1} \times 40 \mathrm{~min} \\
6 \mathrm{mg} \cdot \mathrm{kg}^{-1} \cdot \mathrm{h}^{-1} \times 150 \mathrm{~min} \\
5 \mathrm{mg} \cdot \mathrm{kg}^{-1} \cdot \mathrm{h}^{-1} \text { ensuite }\end{array}$ \\
\hline $\begin{array}{l}\text { Bolus } \\
\text { Perfusion } 1 \\
\text { Perfusion } 2 \\
\text { Perfusion } 3\end{array}$ & $\begin{array}{l}25 \mu \mathrm{g} \cdot \mathrm{kg}^{-1} \text { en } 30 \mathrm{~s} \\
25 \mu \mathrm{g} \cdot \mathrm{kg}^{-1} \cdot \mathrm{h}^{-1} \text { x } 30 \mathrm{~min} \\
30 \mu \mathrm{g} \cdot \mathrm{kg}^{-1} \cdot \mathrm{h}^{-1} \text { ensuite }\end{array}$ & $\begin{array}{l}3 \mu \mathrm{g} \cdot \mathrm{kg}^{-1} \text { en } 30 \mathrm{~s} \\
1,5 \mu \mathrm{g} \cdot \mathrm{kg}^{-1} \cdot \mathrm{h}^{-1} \text { x } 30 \mathrm{~min} \\
1,3 \mu \mathrm{g} \cdot \mathrm{kg}^{-1} \cdot \mathrm{h}^{-1} \times 120 \mathrm{~min} \\
0,7 \mu \mathrm{g} \cdot \mathrm{kg}^{-1} \cdot \mathrm{h}^{-1} \text { ensuite }\end{array}$ & $\begin{array}{l}0,15 \mu \mathrm{\mu g} \cdot \mathrm{kg}^{-1} \text { en } 30 \mathrm{~s} \\
0,15 \mu \mathrm{g} \cdot \mathrm{kg}^{-1} \cdot \mathrm{h}^{-1} \text { ensuite } \\
11,5 \mu \mathrm{g} \cdot \mathrm{kg}^{-1} \cdot \mathrm{h}^{-1} \text { ensuite }\end{array}$ & $\begin{array}{l}1,5 \mu \mathrm{g} \cdot \mathrm{kg}^{-1} \text { en } 30 \mathrm{~s} \\
13 \mu \mathrm{g} \cdot \mathrm{kg}^{-1} \cdot \mathrm{h}^{-1} \times 20 \mathrm{~min}\end{array}$ \\
\hline
\end{tabular}


tiques pour le propofol, l'alfentanil, le fentanyl et le sufentanil. Selon le modèle, pour faire passer les concentrations du site d'effet d'une $\mathrm{C}_{\mathrm{P}_{50}}$ à une $\mathrm{C}_{\mathrm{P}_{95}}$, on augmente le propofol de $30 \%$ et les fentanyl, sufentanil et rémifentanil de $25 \%$. Ce qui signifie, en pratique, que changer la profondeur de l'anesthésie c'est changer les deux perfusions proportionnellement. Donc, pour augmenter la profondeur de l'anesthésie, chaque perfusion (ou chaque cible dans le cas d'une PCC) est augmentée du même pourcentage. Le modèle nous enseigne aussi, avec le rémifentanil, que la façon idéale de modifier les niveaux d'anesthésie est de modifier la vitesse de perfusion du rémifentanil et de garder la vitesse du propofol constante.

$\mathrm{La} \mathrm{CP}_{50}$ a été choisie pour la Table III, vu qu'elle semble représenter de bons schémas de base pour les situations réelles. Le bolus initial correspond à des doses d'induction raisonnables et la profondeur d'anesthésie nécessaire pour la préparation de la peau n'exige sûrement pas de $\mathrm{Cp}_{50}$ plus élevée que celle obtenue avec les vitesses de perfusion recommandées. Une planification adaptée permettra d'augmenter la profondeur de l'anesthésie en prévision de l'incision cutanée en appliquant les principes de changements proportionnels décrits plus haut.

Quelques remarques s'imposent au sujet de l'application clinique du modèle. Idéalement, on utilise un dispositif de PCC. Les changements de concentration produits au site effecteur sont la conséquence presque immédiate de l'administration d'un bolus suivie d'une perfusion. La plupart des cliniciens utilisant les perfusions manuelles, ils doivent se rappeler que les changements de profondeur de l'anesthésie se produiront plus lentement. Notons aussi qu'une combinaison particulière de propofol/opioïde (concentrations cibles) demeure la même, quelle que soit la durée de la perfusion, mais la récupération sera plus tardive si la perfusion dure plus longtemps.

L'emploi d'une combinaison de propofol/rémifentanil doit être mise en perspective. La Table III montre que la $\mathrm{Cp}_{50}$ du propofol obtenue avec la vitesse de perfusion proposée est de $2,5 \mu \mathrm{g} \cdot \mathrm{ml}^{-1}$. Comme le montre la Table II, cette concentration entrainera une réaction à des commandes verbales chez $50 \%$ des sujets. Si la prescription de dosage est suivie et que la perfusion de rémifentanil est interrompue par inadvertance, les niveaux d'opioïde vont baisser très rapidement et une proportion significative de patients pourrait s'éveiller. Face à ce problème, il est sans doute plus sûr de faire circuler la perfusion de propofol à une vitesse légèrement plus élevée et une perfusion de rémifentanil à une vitesse plus lente. D'après les simulations de Vuyk, la récupération se fera quand même rapidement.
Enfin, on doit aussi considérer des facteurs individuels comme l'âge, l'état physiologique, le poids et les processus morbides, qui peuvent tous influencer la pharmacocinétique et la pharmacodynamie. Encore une fois, de meilleurs techniques de modélisation et des études plus avancées pourront améliorer nos connaissances et, de ce fait, les régimes de dosage. C'est illustré avec justesse dans une récente étude de Egan $e t$ coll. où les auteurs montrent que l'administration de rémifentanil doit être basée sur la masse maigre de l'organisme plutôt que sur la masse totale. Dans l'éditorial qui l'accompagne, Bouillon et Shafer suggèrent un nomogramme, pour la détermination du poids, qui pourrait être utilisé pour la graduation des mesures. Ces recommandations pourraient s'appliquer aux vitesses de perfusions suggérées à la Table III.

De meilleures connaissances de la pharmacologie sont à l'origine de meilleurs soins. Le savoir empirique, le sens commun et l'observation clinique astucieuse aident sûrement à établir un schéma de dosage judicieux, mais l'évidence scientifique est nécessaire pour comprendre pleinement la complexité de la pharmacologie et de l'interaction médicamenteuse.

\section{Références}

(Voir page R125) 